\title{
Somatic GATA5 mutations in sporadic tetralogy of Fallot
}

\author{
RI-TAI HUANG ${ }^{1}$, SONG XUE $^{1}$, YING-JIA XU ${ }^{2}$, MIN ZHOU $^{1}$ and YI-QING YANG ${ }^{2-4}$ \\ ${ }^{1}$ Department of Cardiovascular Surgery, Renji Hospital, School of Medicine, Shanghai Jiao Tong University, Shanghai 200127; \\ ${ }^{2}$ Department of Cardiology, ${ }^{3}$ Cardiovascular Research Laboratory and ${ }^{4}$ Central Laboratory, Shanghai Chest Hospital, \\ Shanghai Jiao Tong University, Shanghai 200030, P.R. China
}

Received October 27, 2013; Accepted February 11, 2014

DOI: $10.3892 / \mathrm{ijmm} .2014 .1674$

\begin{abstract}
Tetralogy of Fallot (TOF) is the most common form of cyanotic congenital heart disease, with high morbidity and mortality rates. Accumulating evidence has demonstrated that genetic defects play an important role in the pathogenesis of TOF. However, the molecular basis of TOF in the majority of patients remains to be determined. In the present study, sequence analysis of the coding exons and exon-intron boundaries of GATA5, a gene encoding a zinc finger-containing transcriptional factor crucial for cardiogenesis, was performed on genomic DNA isolated from resected cardiac tissue and matched blood samples of 85 unrelated patients who underwent surgical repair of TOF. Genotyping was performed on the cardiac tissue and matched blood samples from 63 unrelated patients who underwent cardiac valve replacement due to rheumatic heart disease as well as the blood samples obtained from 200 unrelated healthy individuals. The functional effect of the mutations was evaluated by using a luciferase reporter assay system. As a result, the novel heterozygous GATA5 mutations, p.D203E and p.Y208X, were found in the cardiac tissues of two TOF patients, respectively. There were no mutations in the cardiac tissues obtained from 63 patients with rheumatic heart disease nor in the blood samples obtained from the 348 subjects. Functional analysis revealed that the GATA5 mutants were consistently associated with significantly decreased transcriptional activity compared with their wild-type counterpart. Thus, results of this study showed an association of somatic GATA5 mutations with TOF, providing further insight into the underlying molecular mechanism of TOF.
\end{abstract}

Correspondence to: Professor Song Xue, Department of Cardiovascular Surgery, Renji Hospital, School of Medicine, Shanghai Jiao Tong University, 1630 Dongfang Road, Shanghai 200127, P.R. China E-mail: xuesong64@163.com

Dr Yi-Qing Yang, Cardiovascular Research Laboratory, Shanghai Chest Hospital, Shanghai Jiao Tong University, 241 West Huaihai Road, Shanghai 200030, P.R. China

E-mail: yang99yang66@hotmail.com

Key words: congenital heart disease, tetralogy of Fallot, genetics, transcription factor, GATA5, reporter gene analysis

\section{Introduction}

Congenital heart disease (CHD) is the most common type of birth defect in newborns, affecting $\sim 1 \%$ of all live births, and is the most frequent non-infectious cause of infant death, responsible for at least $10 \%$ of early miscarriages (1). Based on specific anatomic or hemodynamic lesions, CHD is clinically classified into $>21$ distinct categories, of which tetralogy of Fallot (TOF), a tetrad of ventricular septal defect, right ventricular outflow tract obstruction, overriding aorta, and right ventricular hypertrophy, is the most common form of cyanotic CHD. TOF occurs in $\sim 3 / 10,000$ neonates alive, accounting for $\sim 7-10 \%$ of all congenital cardiac malformations. Surgical treatment is crucial, otherwise $25 \%$ of TOF patients with severe obstruction would succumb to CHD in the first year of life, $40 \%$ by the age of 3 years, $70 \%$ by 10 years and $95 \%$ by 40 years (1-3). Various cardiovascular developmental abnormalities, such as ventricular septal defect, atrial septal defect, tetralogy of Fallot, patent ductus arteriosis, atrioventricular septal defect, double outlet right ventricle, pulmonary stenosis, and transposition of great arteries, may occur individually or in combination. These anomalies may result in degraded quality of life, delayed fetal brain development, cardiac enlargement or hypertrophy, pulmonary hypertension, infective endocarditis, thromboembolism, Eisenmenger's syndrome, congestive heart failure, arrhythmias, as well as sudden cardiac death in the absence of surgical or catheter-based repairs (4-10). Despite the high prevalence and significant clinical importance, the molecular mechanism of CHD remains poorly understood (11).

In vertebrate embryo, the heart is the first functional organ to form and embryonic heart development involves five sequential stages, including heart tube formation, cardiac looping, septal formation, outflow tract septation and heart valve formation. Thus it is obvious that cardiogenesis is a complex and dynamic process, which requires the harmonious orchestration of cardiac cell commitment, differentiation, proliferation and migration, and both environmental and genetic risk factors may disrupt the finely regulated biological process, resulting in CHD (12-14). Mounting evidence has demonstrated that an evolutionarily conserved network of transcription factors connecting signaling pathways with genes related to muscle growth, patterning, and contractility, including the most extensively investigated GATA and NK families, are crucial in cardiovascular morphogenesis (15-17), and germline mutations in NKX2-5 (18-28), GATA4 (29-41), GATA5 (42-46), and GATA6 (47-55) have been 
associated with CHD. Nevertheless, the genetic basis underlying CHD remains to be clarified. Patients may have mutations in other genes: mutations in TBX5 and FOXC1 have been found to be involved in CHD, although these CHD-associated mutations seem to be rare and in most cases are associated with extra-cardiac anomalies, a syndromic phenotype $(56,57)$. Another possible explanation for the incomplete identification of mutation-positive CHD may be somatic mosaicism.

In genetics, somatic mosaicism refers to the condition in which multiple cell clones with distinct genotypes exist in the same individual that has developed from a single fertilized zygote. Somatic mutation leading to mosaicism is prevalent in cancer and is responsible for most leukemia, lymphomas and solid tumors (58). Somatic mutations have been identified in GATA4 and GATA6 as well as their transcriptionally cooperative partners, NXK2-5 and TBX5, in the cardiac tissue derived from a collection of hearts with CHD (59-68). The expression and function of GATA5, a member of the GATA family, overlap at least partially with those of GATA4, GATA6, NKX2-5 and TBX5 during embryogenesis (12-17). Thus, it may be hypothesized that somatic GATA5 mutations potentially underlie TOF in a subset of patients.

In the present study, in order to determine the prevalence and spectrum of somatic GATA5 mutations in patients with sporadic TOF and explore the mechanism by which mutated GATA5 confers susceptibility to TOF, the coding regions and splice junction sites of GATA5 were analyzed in patients as compared to control individuals, and the functional effect of the mutant GATA5 was characterized as compared to its wild-type counterpart using a luciferase reporter assay system.

\section{Materials and methods}

Study participants. The study included a cohort of 85 unrelated patients with sporadic TOF, who underwent heart surgery at the Shanghai Renji Hospital in China during the period January 2009 to June 2013. The age range was 5 months to 8 years, with an average of 1.46 years at the time of surgical repair. Skillful cardiologists assessed the patients and a diagnosis of TOF was made using echocardiography and confirmed by direct view during surgery. The patients with known chromosomal abnormalities or syndromic cardiac deformities, such as Holt-Oram, Noonan, Alagille, DiGeorge, Marfan and Char syndrome, were excluded from the present study. According to the report by Draus et al (66), the sample size was sufficient to conclude that the absence of somatic mutations was significant.

Controls included 63 unrelated patients $(35$ males and 28 females) with rheumatic heart disease undergoing cardiac valve replacement, and 200 unrelated healthy individuals (110 males and 90 females) randomly selected from those undergoing routine physical examinations. Based on the individual medical history and echocardiographic record, the control individuals had no overt congenital cardiovascular deformations, apart from subclinical cardiac aberrations such as bicuspid aortic valve or patent foramen ovale.

All the participants were Chinese Han. The ethnic origin of a subject was ascertained by a combination of self-reported ethnicity and a personal questionnaire with regards to the birthplace, language, religion and ancestry. The study protocol conformed to the ethical guidelines of the 2008 Declaration of Helsinki and was approved by the local Institutional Ethics Committee. Written informed consent from each participant's guardian was obtained prior to investigation.

Sample preparation. The heart tissues from the right ventricular outflow tracts of TOF patients were resected during the routine cardiac surgery procedures. Following resection, the discarded cardiac tissue samples were collected after cleaning the blood stain by sterile normal saline. The samples were then stored at $-80^{\circ} \mathrm{C}$. Discarded peripheral venous blood samples with sodium citrate were collected from the patients (the blood samples were mostly used for activated partial thromboplastin time and prothrombin time tests prior to surgery). The discarded cardiac samples from the cardiac valves and matched blood samples of the patients undergoing cardiac valve replacement because of rheumatic valvular disease, and the peripheral venous blood samples of healthy individuals were prepared as controls.

DNA isolation. Somatic DNA was isolated from freshly frozen tissues using QIAamp DNA FFPE Tissue kit (Qiagen GmbH, Hilden, Germany) as per the manufacturer's protocol. Genomic DNA was extracted from peripheral blood lymphocytes using a Wizard Genomic DNA Purification kit (Promega, Madison, WI, USA).

Genetic analysis. The primer pairs used to amplify the coding exons and exon-intron boundaries of the GATA5 gene were described in a previous study (46). Polymerase chain reaction (PCR) was carried out in Veriti Thermal Cycler (Applied Biosystems, Foster City, CA, USA). The reaction mixture for PCR included $2 \mu \mathrm{l}$ of genomic DNA (50-100 ng/ $\mu \mathrm{l}), 2.5 \mu \mathrm{l}$ of 10X Taq buffer, $5 \mu \mathrm{l}$ of $5 \mathrm{X}$ Q Solution, $2 \mu \mathrm{l}$ of dNTP mixture (2.5 mM each), $0.5 \mu \mathrm{l}$ of each primer $(20 \mathrm{mM}$ each), $0.25 \mu \mathrm{l}$ (1.25 units) of HotStar TaqDNA polymerase (Qiagen), and $12.25 \mu \mathrm{l}$ of deionized $\mathrm{H}_{2} \mathrm{O}$, with a final volume of $25 \mu \mathrm{l}$. PCR was performed under the following conditions: Pre-denaturation at $95^{\circ} \mathrm{C}$ for $15 \mathrm{~min}$, followed by 35 cycles of denaturation at $95^{\circ} \mathrm{C}$ for $1 \mathrm{~min}$, annealing at $62^{\circ} \mathrm{C}$ for $30 \mathrm{sec}$, and extension at $72^{\circ} \mathrm{C}$ for $1 \mathrm{~min}$, and a final extension at $72^{\circ} \mathrm{C}$ for $10 \mathrm{~min}$. The amplified products were analyzed on $1 \%$ agarose gels stained with ethidium bromide and purified using QIAquick Gel Extraction kit (Qiagen). The two strands of each PCR product were sequenced using a BigDye ${ }^{\circledR}$ Terminator v3.1 Cycle Sequencing kit under an ABI PRISM 3130XL DNA analyzer (both from Applied Biosystems). The sequencing primers were the same as previously designed for specific region amplification. The DNA sequences were analyzed using the DNA Sequencing Analysis Software v5.1 (Applied Biosystems). The sequence variation was validated by re-sequencing an independent PCR-generated amplicon from the same subject. For each GATA5 sequence variation identified in this study, the single-nucleotide polymorphism (SNP) database of the National Center for Biotechnology Information (NCBI; http://www.ncbi.nlm.nih.gov/SNP), the 1000 Genome Project (1000GP) database (http://www.1000genomes.org/), and the Human Gene Mutation (HGM) database (http://www. hgmd.cf.ac.uk/) were searched to confirm its novelty.

Multiple alignments of GATA5 amino acid sequences among species. Alignment of a number of GATA5 amino acid 
sequences across various species was carried out using the online program of Muscle, version 3.6 (http://www.ncbi.nlm. nih.gov/).

Prediction of the disease-causing potential of a GATA5 sequence variation. The causative potential of a GATA5 sequence variation was predicted by the MutationTaster (an online program at http://www.mutationtaster.org), which automatically yielded a probability for the variation to be a disease-causing mutation or a benign polymorphism. In addition, another online program PolyPhen-2 (http://genetics.bwh. harvard.edu/pph2) was also used to evaluate the pathogenicity of an amino acid substitution in GATA5.

Expression plasmids and site-directed mutagenesis. The recombinant expression plasmid pcDNA3.1-hGATA5 was constructed as described previously (46). The atrial natriuretic factor (ANF)-luciferase reporter gene, containing the 2600-bp 5'-flanking region of the ANF gene, i.e., ANF(-2600)-Luc, was kindly provided by Dr Ichiro Shiojima, from the Department of Cardiovascular Science and Medicine, Chiba University Graduate School of Medicine, Chuo-ku, Chiba, Japan. The mutation identified was introduced into the wild-type GATA5 by using a QuikChange II XL Site-Directed Mutagenesis kit (Stratagene, La Jolla, CA, USA) with a complementary pair of primers. The mutant was sequenced to confirm the required mutation and to exclude any other sequence variations.

Reporter gene assay. HEK-293 cells were seeded in Dulbecco's modified Eagle's medium supplemented with $10 \%$ fetal calf serum. The ANF(-2600)-Luc reporter vector and an internal control reporter plasmid pGL4.75 (hRluc/CMV; Promega) were employed in transient transfection assays to examine the transcriptional activation function of the GATA5 mutants. The HEK-293 cells were transfected with $0.4 \mu \mathrm{g}$ of wild-type or mutant pcDNA3.1-hGATA5 expression vector (D203E or $\mathrm{Y} 208 \mathrm{X}), 0.4 \mu \mathrm{g}$ of $\mathrm{ANF}(-2600)$-Luc reporter construct, and $0.04 \mu \mathrm{g}$ of pGL4.75 control reporter vector using Lipofectamine 2000 transfection reagent (Invitrogen, Carlsbad, CA, USA). For co-transfection experiments, $0.2 \mu \mathrm{g}$ of wild-type pcDNA3.1-hGATA5, $0.2 \mu \mathrm{g}$ of empty pcDNA3.1 plasmid or $0.2 \mu \mathrm{g}$ of mutant pcDNA3.1-hGATA5 (D203E or Y208X), $0.4 \mu \mathrm{g}$ of ANF(-2600)-Luc, and $0.04 \mu \mathrm{g}$ of pGL4.75 were used. Firefly luciferase and Renilla luciferase activities were measured with the Dual-Glo luciferase assay system (Promega) $48 \mathrm{~h}$ after transfection. The activity of the $A N F$ promoter was presented as fold activation of Firefly luciferase relative to Renilla luciferase. Three independent experiments were performed at minimum for wild-type and mutant GATA5.

Statistical analysis. Data were presented as means \pm standard deviation. Continuous variables were tested for normality of distribution. The Student's unpaired t-test was utilized to compare numeric variables between 2 groups. A two-tailed $\mathrm{P}$-value $<0.05$ indicated a significant difference.

\section{Results}

Clinical characteristics of the study subjects. This study included a cohort of 85 unrelated patients with sporadic
TOF who underwent cardiac surgery, 63 unrelated patients undergoing cardiac valve replacement due to rheumatic heart disease and 200 healthy individuals used as controls. All the subjects were Chinese Han and did not have a positive family history of CHD or established environmental risk factors for CHD, such as maternal illness and drug use during the first trimester of pregnancy, parental smoking, or chronic exposure to toxicants and ionizing radiation. The baseline clinical characteristics of the 348 participants are provided in Table I.

Sample sources. Peripheral venous blood samples were obtained from the 348 participants. Malformed myocardial tissue samples were collected from 85 unrelated patients with sporadic TOF who underwent surgical resection of the right ventricular outflow musculature to relieve stenosis. The cardiac muscle fragment collected was $\sim 5 \times 5 \mathrm{~mm}$ in size. The cardiac valvular tissue samples used as controls were obtained from surgical discards of the 63 unrelated patients undergoing cardiac valve replacement.

GATA5 mutations. Genomic DNA from the malformed cardiac tissues of 85 patients with sporadic TOF, the cardiac valvular tissues of 63 cases with rheumatic heart disease, and the peripheral blood lymphocytes of all the 348 participants, were genetically scanned for GATA 5 mutations. Two heterozygous GATA5 mutations were identified in the fresh pathological myocardial tissues of two unrelated TOF patients, respectively, with a mutational prevalence of $2.35 \%$. Specifically, a substitution of guanine for cytosine in the third nucleotide of codon 203 of the GATA5 gene (c.609C $>\mathrm{G}$ ), predicting the transition of aspartic to glutamic acid at amino acid position 203 (p.D203E), was identified in the cardiac tissue of a 2 -year-old male TOF patient. A change of cytosine into adenine at coding nucleotide 624 (c.624C $>$ A), resulting in a truncated protein with only N-terminal 207 amino acids left (p.Y208X), was identified in the cardiac tissue of a 1-year-old male TOF patient. The sequence chromatograms showing the detected heterozygous GATA5 mutations as compared to their corresponding control sequences are shown in Fig. 1. A schematic diagram of GATA5 showing the structural domains and locations of the identified mutations is provided in Fig. 2. The two mutations were not observed in the cardiac valvular tissues of 63 patients with rheumatic heart disease or identfied in the peripheral blood samples of the 348 participants. Neither mutation was reported in the SNP, 1000 GP and HGM databases, which was consulted again on October 26, 2013. Furthermore, no atrial fibrillation was observed in the two mutation carriers during a $24-\mathrm{h}$ period of ambulatory electrocardiographic monitoring.

Alignment of multiple GATA5 protein sequences across species. Alignment of multiple GATA5 protein sequences across species revealed that the affected amino acids p.D203 and p.Y208 were completely conserved evolutionarily (Fig. 3). Furthermore, the p.Y208X mutation deleted a number of functionally important structural domains, including the nuclear localization signal, C-terminal zinc finger and part of the N-terminal zinc finger (Fig. 2). 
Table I. Baseline clinical characteristics of the 85 unrelated patients with sporadic tetralogy of Fallot (TOF).

Variable

Male gender, n (\%)

Age at the initial diagnosis of TOF (year)

Age at the time of surgery (year)

Positive family history of TOF, n (\%)

Distribution of various types of TOF, n (\%)

Isolated TOF

TOF and bicuspid pulmonary valve

TOF and pulmonary stenosis

TOF and right-sided aortic arch

TOF and atrial septal defect

TOF and atrioventricular septal defect

TOF and anomalous pulmonary venous return

TOF and at least two other anatomical defects

Incidence of arrhythmias, n (\%)

Atrioventricular block

Atrial fibrillation

Treatment, n (\%)

Surgical repair
Statistic

47 (55.29)

$1.02 \pm 0.85$

$1.46 \pm 1.19$

$0(0)$

$42(49.41)$

14 (16.47)

$10(11.76)$

$8(9.41)$

5 (5.88)

1 (1.18)

1 (1.18)

4 (4.71)

4 (4.71)

85 (100)

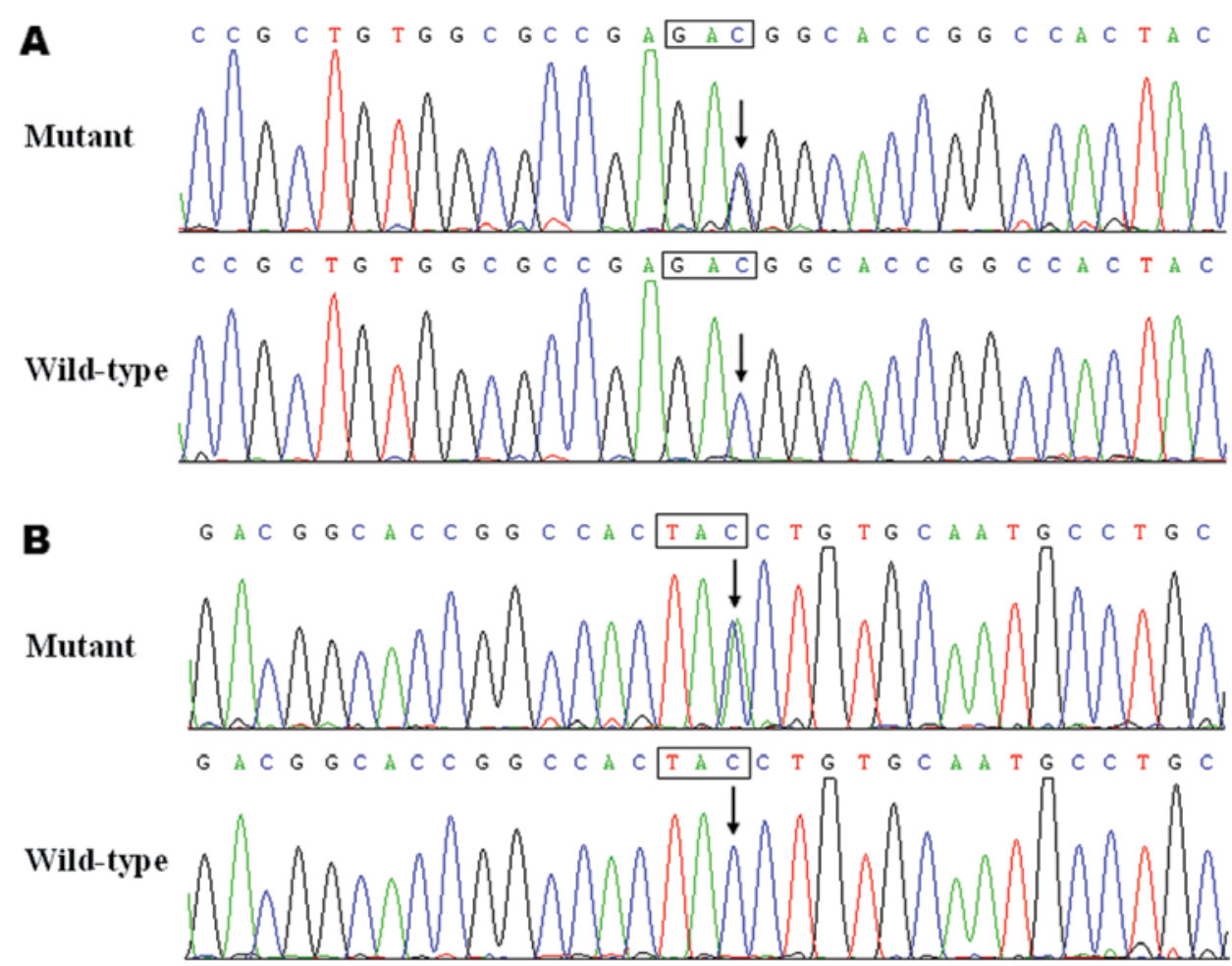

Figure 1. Sequence electropherograms showing the GATA5 mutations as well as their corresponding controls. The arrows indicate the heterozygous nucleotides of (A) $\mathrm{C} / \mathrm{G}$ and (B) C/A in the 2 unrelated patients, respectively (mutant) or the homozygous nucleotides of $\mathrm{C} / \mathrm{C}$ in the corresponding control individuals (wild-type). The rectangle denotes the nucleotides comprising a codon of GATA5.

Pathogenic potential of GATA5 variations. The nucleotide sequence variations of c. $609 \mathrm{C}>\mathrm{G}$ and c.624C $>\mathrm{A}$ in GATA5 were predicted to be causative by the MutationTaster, with P-values of 0.9995 and 1.0000, respectively. No SNPs were detected in the altered regions in the MutationTaster database. The amino acid substitution of p.D203E in GATA5 was also predicted to be damaging by PolyPhen-2, with a score of 1.000 (sensitivity 0.00 ; specificity 1.00 ). 

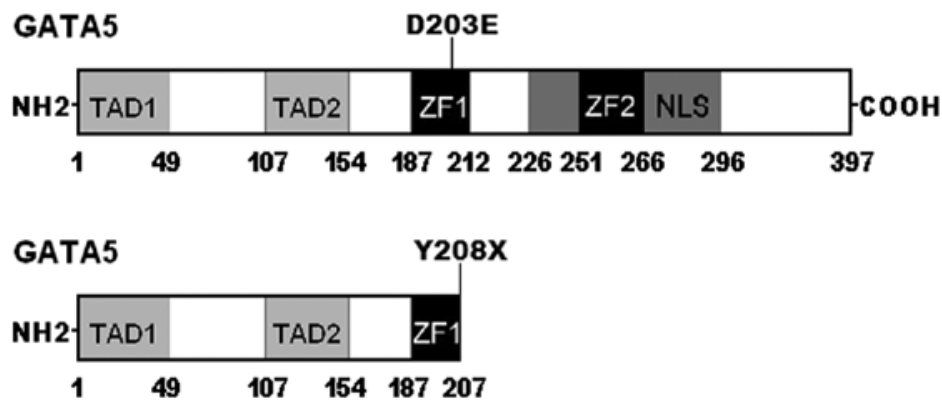

Figure 2. Schematic representation of GATA5 protein structure with the tetralogy of Fallot related mutations indicated. The mutations identified in patients with tetralogy of Fallot are shown above the structural domains. The p.Y208X mutation produces a truncated protein that lacks multiple important structural domains including a small part of ZF1, ZF2, nuclear localization signal, and C-terminus. NH2, amino-terminus; TAD, transcriptional activation domain; ZF, zinc finger; NLS, nuclear localization signal; and $\mathrm{COOH}$, carboxyl-terminus.

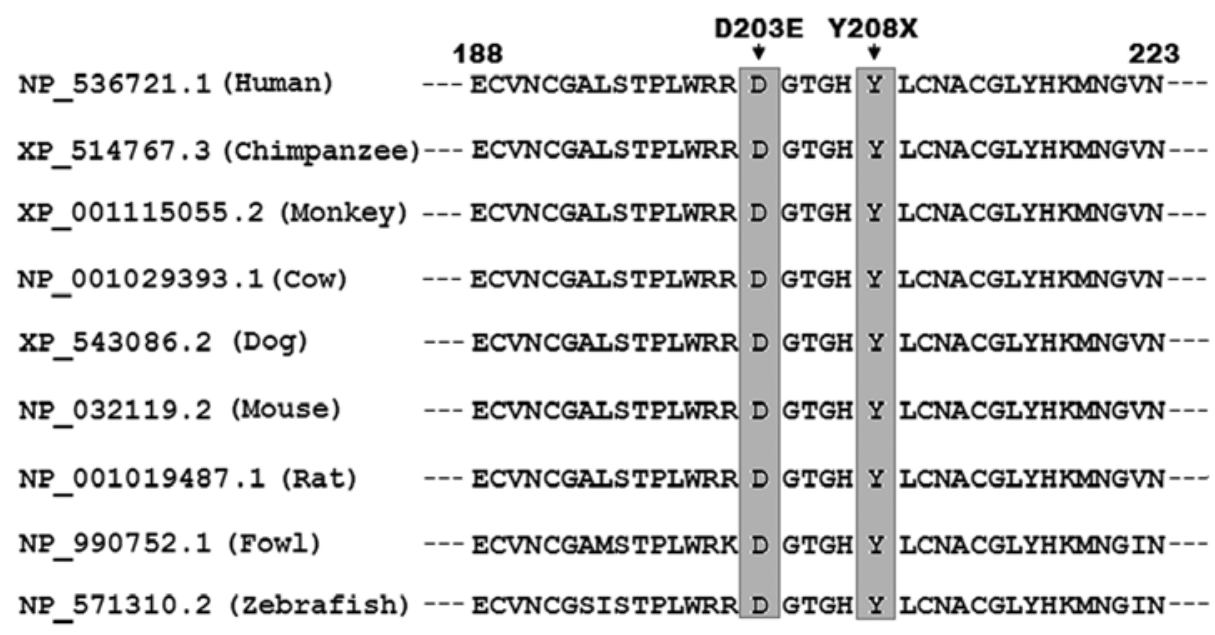

Figure 3. Alignment of multiple GATA5 protein sequences across species. The altered amino acids p.D203 and p.Y208 are completely conserved evolutionarily among a great variety of species.

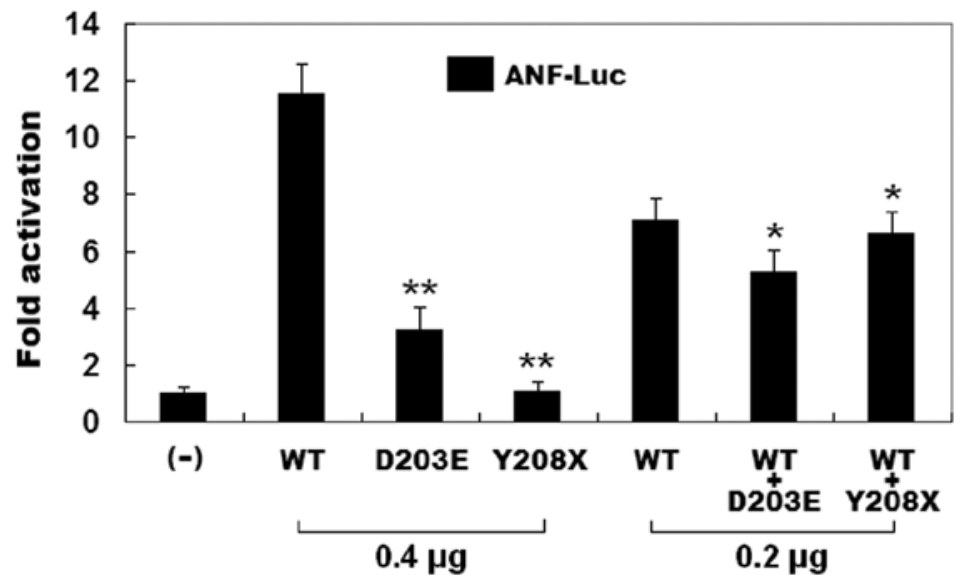

Figure 4. Functional defects resulted from GATA5 mutations. Activation of ANF-luciferase reporter in HEK-293 cells by wild-type (WT) or mutant (D203E or Y208X) GATA5, alone or in combination, showed significantly decreased transcriptional activity by mutant proteins. Experiments were performed in triplicate and mean and standard deviations are shown. ${ }^{* *} \mathrm{P}<0.001$ and ${ }^{*} \mathrm{P}<0.005$, compared with WT GATA5.

Reduced transcriptional activity of the GATA5 mutants. The wild-type GATA5, the D203E-mutant, and the Y208X-mutant GATA5 activated the $A N F$ promoter by $\sim 12-, \sim 3-$ and $\sim 1$-fold, respectively. When wild-type GATA5 was co-expressed with the same amount of D203E- or Y208X-mutant GATA5, the induced activation of the ANF promoter was $\sim 5$ - or $\sim 7$-fold, respectively. Findings of the present study indicate that the two GATA5 mutants are associated with markedly reduced activation activity compared to their wild-type counterpart (Fig. 4). 


\section{Discussion}

In the present study, two novel heterozygous GATA5 mutations, p.D203E and p.Y208X, were identified in the deformed heart tissues from 2 of 85 unrelated patients with TOF. The mutant alleles were absent in the pathogenic cardiac tissues of 63 unrelated patients with rheumatic heart disease and in the peripheral blood samples of all 348 participants, including 200 ethnically matched healthy individuals. A cross-species alignment of multiple GATA5 protein sequences showed that the altered amino acids were completely conserved evolutionarily. The two GATA5 sequence variations were predicted to be pathogenic, and the functional analysis revealed that the mutant GATA5 proteins were associated with significantly decreased or no transcriptional activity. Therefore, it is very likely that somatic GATA5 loss-of-function mutations predispose these two mutation carriers to TOF.

There are two major categories of cells in humans: somatic and germ cells. Somatic cells, also known as body cells, make up the body of an organism, forming all the internal organs, skin, bones, blood, and connective tissue. Numerous endogenous factors such as mobile elements, DNA polymerase slippage, DNA double-strand break, inefficient DNA repair, unbalanced chromosomal segregation and certain exogenous factors such as nicotine and UV exposure can contribute to the generation of somatic mutations, thereby leading to somatic mosaicism (69). Mutations that occur in the genetic material of somatic cells are not transmitted to the next generation, but occur in all cells derived from the mutated cell (70). Therefore, disease-associated somatic mutations can be identified by screening the genetic substance from diseased tissue cells, but cannot be detected by the genetic analysis of DNA from peripheral blood lymphocytes alone, and mosaicism may reduce the likelihood of detection in the affected tissue. Thus, mutations in cardiac tissues may be absent or sporadic in blood lymphocytes of the same person (64). In this study, two novel GATA5 mutations were identified in the anomalous heart tissues, although neither mutation was found in the peripheral blood lymphocytes, suggesting that somatic mutation may be an alternative mechanism of CHD.

GATA transcription factors belong to a group of DNA binding proteins characterized by preferential binding to the consensus DNA sequence (T/A)GATA(A/G) of target gene promoters. At present, six members of the GATA family have been identified in vertebrates, of which GATA1, GATA2 and GATA3 are mainly involved in haematopoiesis and some ectodermal derivatives, whereas GATA4, GATA5 and GATA6 are predominantly associated with cardiogenesis and the formation of certain endoderm-derived tissues in embryonic heart (16). Human GATA5 maps to chromosome 20q13.33 by fluorescence in situ hybridization, which codes for a zinc finger-containing protein with 397 amino acids (71). GATA5 is predicted to comprise two transcriptional activation domains (TADs), two adjacent zinc fingers (ZFs) and one nuclear localization signal (NLS). The two TADs are crucial for the transcriptional activity of GATA5. The C-terminal ZF2 is essential for DNA sequence recognition and binding to the consensus motif, while the N-terminal ZF1 is associated with the sequence specificity and stability of protein-DNA binding.
The NLS is responsible for the sub-cellular trafficking and distribution of GATA5 (46). The GATA5 mutation p.Y208X eliminates the functionally important domains of NLS and ZF2 as well as part of ZF1, and may therefore be expected to nullify GATA5. Another GATA5 mutation p.D203E is located at ZF1, which is likely to reduce the transcriptional activity of GATA5 by interfering with the specific binding and nuclear localization of GATA5.

GATA5 is considered an upstream transcriptional regulator of multiple genes transcribed during embryogenesis, including the genes that encode atrial natriuretic peptide, brain natriuretic peptide, $\alpha$-myosin heavy chain, $\beta$-myosin heavy chain, and cardiac troponin C and I (16). Therefore, the functional roles of the GATA5 mutations may be deciphered by examining the transcriptional activity of the $A N F$ promoter in cultured cells. In this study, the functional effect of the novel GATA5 mutations identified in TOF patients was characterized by the transcriptional activation assay, and the results demonstrated a significantly decreased transcriptional activity on a downstream gene. These data indicate that compromised GATA5 increases the vulnerability to TOF.

It has been reported previously that germline mutations in the GATA5 gene play a role in CHD, including TOF. Jiang et al (42) screened GATA5 in 320 index patients with CHD, and identified four novel heterozygous mutations, including p.R132G, p.V190A, p.A266P and p.H274R, in 4 of 320 unrelated patients with CHD, respectively, with a mutational prevalence of $1.25 \%$. Among these CHD probands harboring GATA5 mutations, one V190A-mutation carrier and one A266P-mutation carrier presented with TOF. However, the functional characteristics of these CHD-related GATA5 mutations remain to be delineated. Wei et al (43) genotyped GATA5 in 130 unrelated patients with TOF, and detected the novel heterozygous GATA5 mutations, p.R187G and p.H207R, in two families with autosomal dominantly inherited TOF, respectively, with a mutational prevalence of $\sim 1.54 \%$ based on the proband population. Functional analysis revealed that the GATA5 mutants were consistently associated with significantly decreased transcriptional activation. Additionally, Wei et al (44) performed sequence analysis of GATA5 in 120 unrelated patients with congenital ventricular septal defect and identified a novel heterozygous mutation of p.L199V in one patient with a positive family history, with a mutational prevalence of $\sim 0.83 \%$. Biochemical assays demonstrated that the mutant GATA5 had significantly decreased transcriptional activity. Moreover, some carriers with GATA5 mutation of p.W200G, p.K218T or p.A266P had congenital cardiac septal defect in addition to atrial fibrillation $(45,46)$. However, in the present study, no germline GATA5 mutation was detected with the exception of two somatic GATA5 mutations, which underscores a genetic mosaic basis for the pathogenesis of TOF in a subset of patients.

The association of genetically impaired GATA5 with enhanced susceptibility to CHD has been demonstrated in animal experiments. In Xenopus, GATA5 is required for the early development of the embryonic heart and acts earlier than GATA4 and GATA6 to regulate cardiac morphogenesis. Downregulation of GATA5 in Xenopus laevis and Xenopus tropicalis by using two non-overlapping translation-blocking 
morpholino oligonucleotides and by using a splice-site blocking morpholino oligonucleotide leads to a substantial reduction in the number of heart precursors at the time of or shortly after their specification (72). In zebrafish, targeted disruption of the GATA5 gene resulted in embryonic lethality due to defects in endocardial and myocardial differentiation and migration, a similar phenotype to cardia bifida of GATA4-null zebrafish (73). Although the GATA5-null mice were viable and had no apparent cardiac defects, the mice that were compound heterozygous for GATA5 and GATA4 or for GATA5 and GATA6 knockout died embryonically or perinatally because of severe defects of the outflow tract development, including double outlet right ventricle and ventricular septal defect (74). These experimental findings highlight the exquisite sensitivity of the developing cardiovascular system to the levels of GATA4, GATA5 and GATA6, and indicate that these GATA factors act synergistically to regulate target genes.

In conclusion, the present study has demonstrated an association between somatic GATA5 loss-of-function mutations and TOF, providing insight into the molecular mechanism of CHD, and suggesting the potential implications for the antenatal diagnosis and potentially the personalized strategy of CHD.

\section{Acknowledgements}

We are sincerely grateful to the participants for their devotion to the study. This study was supported in part by grants from the National Natural Science Fund of China (nos. 81270161, 81070153 and 30570768), the National Basic Research Program of China (2010CB912604), the Personnel Development Foundation of Shanghai, China (2010019), the Natural Science Fund of Shanghai, China (10ZR1428000), and the Key Program of Basic Research of Shanghai, China (10JC1414002).

\section{References}

1. Roger VL, Go AS, Lloyd-Jones DM, Benjamin EJ, Berry JD, Borden WB, Bravata DM, Dai S, Ford ES, Fox CS, Fullerton HJ, Gillespie C, Hailpern SM, Heit JA, Howard VJ, Kissela BM, Kittner SJ, Lackland DT, Lichtman JH, Lisabeth LD, Makuc DM, Marcus GM, Marelli A, Matchar DB, Moy CS, Mozaffarian D, Mussolino ME, Nichol G, Paynter NP, Soliman EZ, Sorlie PD, Sotoodehnia N, Turan TN, Virani SS, Wong ND, Woo D and Turner MB; American Heart Association Statistics Committee and Stroke Statistics Subcommittee: Heart disease and stroke statistics - 2012 update: a report from the American Heart Association. Circulation 125: e2-e220, 2012.

2. van der Linde D, Konings EE, Slager MA, Witsenburg M, Helbing WA, Takkenberg JJ and Roos-Hesselink JW: Birth prevalence of congenital heart disease worldwide: a systematic review and meta-analysis. J Am Coll Cardiol 58: 2241-2247, 2011.

3. Starr JP: Tetralogy of Fallot: yesterday and today. World J Surg 34: 658-668, 2010

4. Müller J, Hess J and Hager A: Exercise performance and quality of life is more impaired in Eisenmenger syndrome than in complex cyanotic congenital heart disease with pulmonary stenosis. Int J Cardiol 150: 177-181, 2011.

5. Müller J, Hess J and Hager A: Minor symptoms of depression in patients with congenital heart disease have a larger impact on quality of life than limited exercise capacity. Int J Cardiol 154 265-269, 2012.

6. Donofrio MT, Duplessis AJ and Limperopoulos C: Impact of congenital heart disease on fetal brain development and injury. Curr Opin Pediatr 23: 502-511, 2011.
7. Gupta V, Tonelli AR and Krasuski RA: Congenital heart disease and pulmonary hypertension. Heart Fail Clin 8: 427-445, 2012.

8. Knirsch W and Nadal D: Infective endocarditis in congenital heart disease. Eur J Pediatr 170: 1111-1127, 2011.

9. Bolger AP, Coats AJ and Gatzoulis MA: Congenital heart disease: the original heart failure syndrome. Eur Heart J 24: 970-976, 2003.

10. Perry JC: Sudden cardiac death and malignant arrhythmias: the scope of the problem in adult congenital heart patients. Pediatr Cardiol 33: 484-490, 2012.

11. Blue GM, Kirk EP, Sholler GF, Harvey RP and Winlaw DS: Congenital heart disease: current knowledge about causes and inheritance. Med J Aust 197: 155-159, 2012.

12. McCulley DJ and Black B: Transcription factor pathways and congenital heart disease. Curr Top Dev Biol 100: 253-277, 2012.

13. Bruneau BG: The developmental genetics of congenital heart disease. Nature 451: 943-948, 2008.

14. Cecchetto A, Rampazzo A, Angelini A, Bianco LD, Padalino M, Stellin G and Daliento L: From molecular mechanisms of cardiac development to genetic substrate of congenital heart diseases. Future Cardiol 6: 373-393, 2010.

15. Olson EN: Gene regulatory networks in the evolution and development of the heart. Science 313: 1922-1927, 2006.

16. Pikkarainen S, Tokola H, Kerkelä R and Ruskoaho H: GATA transcription factors in the developing and adult heart. Cardiovasc Res 63: 196-207, 2004.

17. Bartlett H, Veenstra GJ and Weeks DL: Examining the cardiac NK-2 genes in early heart development. Pediatr Cardiol 31: $335-341,2010$.

18. Schott JJ, Benson DW, Basson CT, Pease W, Silberbach GM, Moak JP, Maron BJ, Seidman CE and Seidman JG: Congenital heart disease caused by mutations in the transcription factor NKX2-5. Science 281: 108-111, 1998.

19. Reamon-Buettner SM and Borlak J: NKX2-5: an update on this hypermutable homeodomain protein and its role in human congenital heart disease (CHD). Hum Mutat 31: 1185-1194, 2010.

20. Stallmeyer B, Fenge H, Nowak-Göttl U and Schulze-Bahr E: Mutational spectrum in the cardiac transcription factor gene NKX2.5 (CSX) associated with congenital heart disease. Clin Genet 78: 533-540, 2010.

21. Ouyang P, Saarel E, Bai Y, Luo C, Lv Q, Xu Y, Wang F, Fan C, Younoszai A, Chen Q, Tu X and Wang QK: A de novo mutation in NKX2.5 associated with atrial septal defects, ventricular noncompaction, syncope and sudden death. Clin Chim Acta 412: 170-175, 2011.

22. Liu XY, Wang J, Yang YQ, Zhang YY, Chen XZ, Zhang W, Wang XZ, Zheng JH and Chen YH: Novel NKX2-5 mutations in patients with familial atrial atrial septal defects. Pediatr Cardiol 32: 193-201, 2011.

23. Wang J, Xin YF, Liu XY, Liu ZM, Wang XZ and Yang YQ: A novel NKX2-5 mutation in familial ventricular septal defect. Int J Mol Med 27: 369-375, 2011

24. Wang J, Liu XY and Yang YQ: Novel NKX2-5 mutations responsible for congenital heart disease. Genet Mol Res 10: 2905-2915, 2011

25. Granados-Riveron JT, Pope M, Bu'lock FA, Thornborough C, Eason J, Setchfield K, Ketley A, Kirk EP, Fatkin D, Feneley MP, Harvey RP and Brook JD: Combined mutation screening of NKX2-5, GATA4, and TBX5 in congenital heart disease: multiple heterozygosity and novel mutations. Congenit Heart Dis 7: $151-159,2012$.

26. Huang RT, Xue S, Xu YJ, Zhou M and Yang YQ: A novel NKX2.5 loss-of-function mutation responsible for familial atrial fibrillation. Int J Mol Med 31: 1119-1126, 2013.

27. Costa MW, Guo G, Wolstein O, Vale M, Castro ML, Wang L, Otway R, Riek P, Cochrane N, Furtado M, Semsarian C, Weintraub RG, Yeoh T, Hayward C, Keogh A, Macdonald P, Feneley M, Graham RM, Seidman JG, Seidman CE, Rosenthal N, Fatkin D and Harvey RP: Functional characterization of a novel mutation in NKX2-5 associated with congenital heart disease and adult-onset cardiomyopathy. Circ Cardiovasc Genet 6: 238-247, 2013.

28. Xie WH, Chang C, Xu YJ, Li RG, Qu XK, Fang WY, Liu X and Yang YQ: Prevalence and spectrum of Nkx2.5 mutations associated with idiopathic atrial fibrillation. Clinics (Sao Paulo) 68: 777-784, 2013.

29. Garg V, Kathiriya IS, Barnes R, Schluterman MK, King IN, Butler CA, Rothrock CR, Eapen RS, Hirayama-Yamada K, Joo K, Matsuoka R, Cohen JC and Srivastava D: GATA4 mutations cause human congenital heart defects and reveal an interaction with TBX5. Nature 424: 443-447, 2003. 
30. Peng T, Wang L, Zhou SF and Li X: Mutations of the GATA4 and NKX2.5 genes in Chinese pediatric patients with non-familial congenital heart disease. Genetica 138: 1231-1240, 2010.

31. Chen Y, Mao J, Sun Y, Zhang Q, Cheng HB, Yan WH, Choy KW and Li H: A novel mutation of GATA4 in a familial atrial septal defect. Clin Chim Acta 411: 1741-1745, 2010.

32. Butler TL, Esposito G, Blue GM, Cole AD, Costa MW, Waddell LB, Walizada G, Sholler GF, Kirk EP, Feneley M, Harvey RP and Winlaw DS: GATA4 mutations in 357 unrelated patients with congenital heart malformation. Genet Test Mol Biomarkers 14: 797-802, 2010.

33. Liu XY, Wang J, Zheng JH, Bai K, Liu ZM, Wang XZ, Liu X, Fang WY and Yang YQ: Involvement of a novel GATA4 mutation in atrial septal defects. Int J Mol Med 28: 17-23, 2011.

34. Wang J, Fang M, Liu XY, Xin YF, Liu ZM, Chen XZ, Wang XZ, Fang WY, Liu X and Yang YQ: A novel GATA4 mutation responsible for congenital ventricular septal defects. Int J Mol Med 28: 557-564, 2011

35. Yang YQ, Wang MY, Zhang XL, Tan HW, Shi HF, Jiang WF, Wang XH, Fang WY and Liu X: GATA4 loss-of-function mutations in familial atrial fibrillation. Clin Chim Acta 412: $1825-1830,2011$

36. Jiang JQ, Shen FF, Fang WY, Liu X and Yang YQ: Novel GATA4 mutations in lone atrial fibrillation. Int J Mol Med 28: 1025-1032, 2011.

37. Yang YQ, Li L, Wang J, Liu XY, Chen XZ, Zhang W, Wang XZ, Jiang JQ, Liu X and Fang WY: A novel GATA4 loss-of-function mutation associated with congenital ventricular septal defect. Pediatr Cardiol 33: 539-546, 2012.

38. Yang YQ, Wang J, Liu XY, Chen XZ, Zhang W, Wang XZ, Liu X and Fang WY: Novel GATA4 mutations in patients with congenital ventricular septal defects. Med Sci Monit 18 CR344-CR350, 2012

39. Wang J, Sun YM and Yang YQ: Mutation spectrum of the GATA4 gene in patients with idiopathic atrial fibrillation. Mol Biol Rep 39: 8127-8135, 2012.

40. Wang E, Sun S, Qiao B, Duan W, Huang G, An Y, Xu S, Zheng Y, $\mathrm{Su} \mathrm{Z}, \mathrm{Gu} \mathrm{X}$, Jin L and Wang H: Identification of functional mutations in GATA4 in patients with congenital heart disease. PLoS One 8: e62138, 2013.

41. Yang YQ, Gharibeh L, Li RG, Xin YF, Wang J, Liu ZM, Qiu XB Xu YJ, Xu L, Qu XK, Liu X, Fang WY, Huang RT, Xue S and Nemer G: GATA4 loss-of-function mutations underlie familial tetralogy of Fallot. Hum Mutat 34: 1662-1671, 2013.

42. Jiang JQ, Li RG, Wang J, Liu XY, Xu YJ, Fang WY, Chen XZ, Zhang W, Wang XZ and Yang YQ: Prevalence and spectrum of GATA5 mutations associated with congenital heart disease. Int J Cardiol 165: 570-573, 2013.

43. Wei D, Bao H, Zhou N, Zheng GF, Liu XY and Yang YQ GATA5 loss-of-function mutation responsible for the congenital ventriculoseptal defect. Pediatr Cardiol 34: 504-511, 2013.

44. Wei D, Bao H, Liu XY, Zhou N, Wang Q, Li RG, Xu YJ and Yang YQ: GATA5 loss-of-function mutations underlie tetralogy of Fallot. Int J Med Sci 10: 34-42, 2013.

45. Yang YQ, Wang J, Wang XH, Wang Q, Tan HW, Zhang M, Shen FF, Jiang JQ, Fang WY and Liu X: Mutational spectrum of the GATA5 gene associated with familial atrial fibrillation. Int J Cardiol 157: 305-307, 2012

46. Wang XH, Huang CX, Wang Q, Li RG, Xu YJ, Liu X, Fang WY and Yang YQ: A novel GATA5 loss-of-function mutation underlies lone atrial fibrillation. Int J Mol Med 31: 43-50, 2013

47. Kodo K, Nishizawa T, Furutani M, Arai S, Yamamura E, Joo K, Takahashi T, Matsuoka R and Yamagishi H: GATA6 mutations cause human cardiac outflow tract defects by disrupting semaphorin-plexin signaling.ProcNatl Acad SciUSA 106: 13933-13938, 2009.

48. Maitra M, Koenig SN, Srivastava D and Garg V: Identification of GATA6 sequence variants in patients with congenital heart defects. Pediatr Res 68: 281-285, 2010

49. Lin X, Huo Z, Liu X, Zhang Y, Li L, Zhao H, Yan B, Liu Y, Yang Y and Chen YH: A novel GATA6 mutation in patients with tetralogy of Fallot or atrial septal defect. J Hum Genet 55: 662-667, 2010

50. Wang J, Luo XJ, Xin YF, Liu Y, Liu ZM, Wang Q, Li RG, Fang WY, Wang XZ and Yang YQ: Novel GATA6 mutations associated with congenital ventricular septal defect or tetralogy of Fallot. DNA Cell Biol 31: 1610-1617, 2012

51. Zheng GF, Wei D, Zhao H, Zhou N, Yang YQ and Liu XY: A novel GATA6 mutation associated with congenital ventricular septal defect. Int J Mol Med 29: 1065-1071, 2012.
52. Yang YQ, Wang XH, Tan HW, Jiang WF, Fang WY and Liu X Prevalence and spectrum of GATA6 mutations associated with familial atrial fibrillation. Int J Cardiol 155: 494-496, 2012.

53. Li J, Liu WD, Yang ZL and Yang YQ: Novel GATA6 loss-offunction mutation responsible for familial atrial fibrillation. Int $J$ Mol Med 30: 783-790, 2012.

54. Yang YQ, Li L, Wang J, Zhang XL, Li RG, Xu YJ, Tan HW, Wang XH, Jiang JQ, Fang WY and Liu X: GATA6 loss-offunction mutation in atrial fibrillation. Eur J Med Genet 55: 520-526, 2012.

55. Bui PH, Dorrani N, Wong D, Perens G, Dipple KM and Quintero-Rivera F: First report of a de novo 18q11.2 microdeletion including GATA6 associated with complex congenital heart disease and renal abnormalities. Am J Med Genet A 161A: 1773-1778, 2013

56. Mori AD and Bruneau BG: TBX5 mutations and congenital heart disease: Holt-Oram syndrome revealed. Curr Opin Cardiol 19: 211-215, 2004.

57. Gripp KW, Hopkins E, Jenny K, Thacker D and Salvin J: Cardiac anomalies in Axenfeld-Rieger syndrome due to a novel FOXC1 mutation. Am J Med Genet A 161A: 114-119, 2013

58. Jacobs KB, Yeager M, Zhou W, Wacholder S, Wang Z, RodriguezSantiago B, Hutchinson A, Deng X, Liu C, Horner MJ, Cullen M, Epstein CG, Burdett L, Dean MC, Chatterjee N, Sampson J, Chung CC, Kovaks J, Gapstur SM, Stevens VL, Teras LT, Gaudet MM, Albanes D, Weinstein SJ, Virtamo J, Taylor PR, Freedman ND, Abnet CC, Goldstein AM, Hu N, Yu K, Yuan JM, Liao L, Ding T, Qiao YL, Gao YT, Koh WP, Xiang YB, Tang ZZ, Fan JH, Aldrich MC, Amos C, Blot WJ, Bock CH, Gillanders EM, Harris CC, Haiman CA, Henderson BE, Kolonel LN, Le Marchand L, McNeill LH, Rybicki BA, Schwartz AG, Signorello LB, Spitz MR, Wiencke JK, Wrensch M, Wu X, Zanetti KA, Ziegler RG, Figueroa JD, Garcia-Closas M, Malats N, Marenne G, Prokunina-Olsson L, Baris D, Schwenn M, Johnson A, Landi MT, Goldin L, Consonni D, Bertazzi PA, Rotunno M, Rajaraman P, Andersson U, Beane Freeman LE, Berg CD, Buring JE, Butler MA, Carreon T, Feychting M, Ahlbom A, Gaziano JM, Giles GG, Hallmans G, Hankinson SE, Hartge P, Henriksson R, Inskip PD, Johansen C, Landgren A, McKean-Cowdin R, Michaud DS, Melin BS, Peters U, Ruder AM, Sesso HD, Severi G, Shu XO, Visvanathan K, White E, Wolk A, Zeleniuch-Jacquotte A, Zheng W, Silverman DT, Kogevinas M, Gonzalez JR, Villa O, Li D, Duell EJ, Risch HA, Olson SH, Kooperberg C, Wolpin BM, Jiao L, Hassan M, Wheeler W, Arslan AA, Bueno-de-Mesquita HB, Fuchs CS, Gallinger S, Gross MD, Holly EA, Klein AP, LaCroix A, Mandelson MT, Petersen G, Boutron-Ruault MC, Bracci PM, Canzian F, Chang K, Cotterchio M, Giovannucci EL, Goggins M, Hoffman Bolton JA, Jenab M, Khaw KT, Krogh V, Kurtz RC, McWilliams RR, Mendelsohn JB, Rabe KG, Riboli E, Tjønneland A, Tobias GS, Trichopoulos D, Elena JW, Yu H, Amundadottir L, Stolzenberg-Solomon RZ, Kraft P, Schumacher F, Stram D, Savage SA, Mirabello L, Andrulis IL, Wunder JS, Patiño García A, Sierrasesúmaga L, Barkauskas DA, Gorlick RG, Purdue M, Chow WH, Moore LE, Schwartz KL, Davis FG, Hsing AW, Berndt SI, Black A, Wentzensen N, Brinton LA, Lissowska J, Peplonska B, McGlynn KA, Cook MB, Graubard BI, Kratz CP, Greene MH, Erickson RL, Hunter DJ, Thomas G, Hoover RN, Real FX, Fraumeni JF Jr, Caporaso NE, Tucker M, Rothman N, Pérez-Jurado LA and Chanock SJ: Detectable clonal mosaicism and its relationship to aging and cancer. Nat Genet 44: 651-658, 2012.

59. Reamon-Buettner SM and Borlak J: GATA4 zinc finger mutations as a molecular rationale for septation defects of the human heart. J Med Genet 42: e32, 2005.

60. Reamon-Buettner SM, Cho SH and Borlak J: Mutations in the 3'-untranslated region of GATA4 as molecular hotspots for congenital heart disease (CHD). BMC Med Genet 8: 38, 2007.

61. Cheng C, Lin Y, Yang F, Wang W, Wu C, Qin J, Shao X and Zhou L: Mutational screening of affected cardiac tissues and peripheral blood cells identified novel somatic mutations in GATA4 in patients with ventricular septal defect. J Biomed Res 25: 425-430, 2011

62. Huang RT, Xue S, Xu YJ and Yang YQ: Somatic mutations in the GATA6 gene underlie sporadic tetralogy of Fallot. Int J Mol Med 31: 515-518, 2013.

63. Salazar M, Consoli F, Villegas V, Caicedo V, Maddaloni V, Daniele P, Caianiello G, Pachón S, Nuñez F, Limongelli G, Pacileo G, Marino B, Bernal JE, De Luca A and Dallapiccola B: Search of somatic GATA4 and NKX2.5 gene mutations in sporadic septal heart defects. Eur J Med Genet 54: 306-309, 2011. 
64. Reamon-Buettner SM and Borlak J: Somatic NKX2-5 mutations as a novel mechanism of disease in complex congenital heart disease. J Med Genet 41: 684-690, 2004.

65. Reamon-Buettner SM, Hecker H, Spanel-Borowski K, Craatz S Kuenzel E and Borlak J: Novel NKX2-5 mutations in diseased heart tissues of patients with cardiac malformations. Am J Pathol 164: 2117-2125, 2004.

66. Draus JM Jr, Hauck MA, Goetsch M, Austin EH III, TomitaMitchell A and Mitchell ME: Investigation of somatic NKX2-5 mutations in congenital heart disease. J Med Genet 46: 115-122, 2009.

67. Reamon-Buettner SM and Borlak J: TBX5 mutations in non-Holt-Oram syndrome (HOS) malformed hearts. Hum Mutat 24: 104, 2004.

68. Wang J, Lu Y, Chen $\mathrm{H}$, Yin M, Yu T and Fu Q: Investigation of somatic NKX2-5, GATA4 and HAND1 mutations in patients with tetralogy of Fallot. Pathology 43: 322-326, 2011.
69. De S: Somatic mosaicism in healthy human tissues. Trends Genet 27: 217-223, 2011.

70. Feero WG, Guttmacher AE and Collins FS: Genomic medicine an updated primer. N Engl J Med 362: 2001-2011, 2010.

71. Nemer G, Qureshi ST, Malo D and Nemer M: Functional analysis and chromosomal mapping of Gata5, a gene encoding a zinc finger DNA-binding protein. Mamm Genome 10: 993-999, 1999.

72. Haworth KE, Kotecha S, Mohun TJ and Latinkic BV: GATA4 and GATA5 are essential for heart and liver development in Xenopus embryos. BMC Dev Biol 8: 74, 2008.

73. Heicklen-Klein A, McReynolds LJ and Evans T: Using the zebrafish model to study GATA transcription factors. Semin Cell Dev Biol 16: 95-106, 2005.

74. Laforest B and Nemer M: GATA5 interacts with GATA4 and GATA6 in outflow tract development. Dev Biol 358: 368-378, 2011. 